\title{
Reformed Orthodoxy and the Libertas philosophandi in the Netherlands
}

\author{
Henri Krop \\ Erasmus University Rotterdam, Rotterdam, The Netherlands \\ krop@esphil.eur.nl
}

\begin{abstract}
In Reformed lands within seventeenth-century Europe, universities were granted the 'liberty to philosophise.' Yet what did this mean in practice? In the first part of this paper, the notion of 'orthodoxy' will be outlined, and it will be explained how, according to Gisbertus Voetius, 'Christian Freedom' and the 'Libertas philosophandi' might go together. Orthodoxy, however, implied a clearly defined confession as well, circumscribing true faith. As a result, 'academic freedom,' though real in some ways, was necessarily limited. In the second part of this paper, the examples of Antonius Walaeus and Abraham Heidanus will show how both the new and the old philosophy might be presented as being consistent with orthodoxy in seventeenth-century Holland.
\end{abstract}

\section{Keywords}

Libertas philosophandi - Voetius - orthodoxy - (Reformed) confession - Walaeus - Heidanus - Calvinist Cartesianism

\section{Introduction}

In the spring of 1673 , Spinoza rejected the offer of a professorship with the "most ample freedom to philosophize" at Heidelberg University. He argued as follows: "I do not know what the limits of that freedom of philosophising might have to be, for me not to seem to aim at disturbing the publicly established religion."1 Apparently, the Reformed orthodoxy of a State Church coexisted

\footnotetext{
1 Spinoza, "Letter 48," in Spinoza Opera, 4 vols., ed. Carl Gebhardt (Heidelberg, 1925), 4: 236.
} 
side by side with a certain "academic freedom." Why and how could that be possible?

The first part of this paper will outline the notion of orthodoxy as it was widely interpreted among Reformed theologians in the early modern era. Focussing on Voetius, I will argue that orthodoxy, at least on a theoretical level, provided for a "Christian freedom," which included the liberty to philosophise. The second part will show how, in practice, philosophy both new and old was made consistent with orthodoxy, by dealing with the examples of Antonius Walaeus and Abraham Heidanus. The latter theologian justified the adoption of the New Philosophy in theology on the basis of "Christian freedom."

From the fourth century onwards, the word "orthodoxy" came in frequent use among Christian authors. It denoted "true faith" and "genuine doctrine," as taught by the Church and laid down by the ecumenical councils. ${ }^{2}$ This truth had to be defended against all error, dissent, and schism, such as the heresies of Arianism and Pelagianism. Since truth is invariant and universal, Augustine identified orthodoxy with Catholicism. ${ }^{3}$ Later, it became usual to refer to the "orthodox" faith of the Fathers.

Although the post-Reformation period is often referred to as "old-protestant Orthodoxy" in the secondary literature, the history of the notion of "orthodoxy' among Reformed theologians remains unwritten. ${ }^{4}$ The "first generation reformer" Calvin remained fully in line with tradition. According to the Genevan theologian, "orthodoxy" is the true faith held by the ancient Church, the contours of which the Fathers laid down in their never ending battle against the ancient heresy of the Arians (revived in the early modern era by Michael Servetus [ca. 1510-1553]), 5 and the Pelagians (which Albert Pighius [1490-1542] again brought to life). ${ }^{6}$ Unlike his predecessors, however, Calvin reflected the different means to determine orthodoxy. Still seeking a specific line himself,

2 A. Siegfried, "Orthodoxie" I, in Historisches Wörterbuch der Philosophie, ed. Joachim Ritter and Karlfried Gründer, 12 vols. (Darmstadt, 1984), 6: 1380.

3 Augustine, De vera religione c. 5 (PL 34, 127): "Quæ cum ita sint, neque in confusione Paganorum, neque in purgamentis hæreticorum, neque in languore schismaticorum, neque in cæcitate Judæorum quærenda est religio, sed apud eos solos qui Christiani catholici, vel orthodoxi nominantur" and cf. Pseudo-Augustine, Meditationes c. 40 (PL 4O, 925): "Haec est fides catholica et orthodoxa, quam me docuit, ..., Deus."

4 Th. Mahlmann, 'Orthodoxie' II, col. 1382.

5 Jean Calvin, "Defensio orthodoxae fidei de sacra trinitate contra prodigiosos errores Michaelis Serveti," in Tractatus theologici omnes (Amsterdam: Johannes Jacob Schipper, 1667), 510-567.

6 Jean Calvin, Defensio sanae et orthodoxae doctrinae de servitute et liberatione humani arbitrii (Genève: Jean Girard, 1543), 119-177. Pighius is challenged to produce one Father who shares his ideas about free will (169) and Calvin refers to the unanimous judgement of the Fathers $(159,132)$, and the Council of Orange (142). 
his ideas do not fit in the rigid confessional frameworks developed towards the end of the sixteenth century. Orthodoxy, according to Calvin, is determined on the one hand by the consensus of tradition. It is primarily the Nicene Creed, which laid down what the Apostles and the "catholic" prophets had taught from ancient times onwards. The Church of the Old and New Testament unanimously adopted this doctrine, ${ }^{7}$ according to which "orthodoxy" is based upon the sacred Fathers. ${ }^{8}$ Additionally, all orthodox theologians defended genuine faith against heresy by means of the Word of God. ${ }^{9}$ However, Calvin observed that Scripture and tradition are linked, because it might well be that an individual errs in understanding the Bible, although it is impossible that the whole Church errs. ${ }^{10}$ In this way, orthodox faith is perspicuous, simple, and plausible. ${ }^{11}$ Finally, it should be noted that, in the Institutions, Calvin opposed Reformed orthodoxy and Roman Catholicism only once. ${ }^{12}$

In the seventeenth century, the concept of orthodoxy is rarely defined. Only the encyclopaedia of Micraelius gives the following short definition: "Theologians call it the pure and sincere doctrine of faith and religion. It is opposed to heresy and error in explaining the word of God."13 By linking orthodoxy with the explanation of the Bible, the protestant nature of this definition is obvious.

The first prominent seventeenth-century Dutch theologian to be dealt with is Antonius Walaeus (1573-1639). After the Synod of Dordt, he was appointed "first professor" of theology at Leiden University. Like Calvin, Walaeus largely follows traditional lines and circumscribes orthodoxy as all doctrines that are

7 Jean Calvin, "Defensio orthodoxae fidei," (see above, n. 5), 538: "Unde certum est, in Concilio Niceno Ecclesiæ præsides non aliud nobis Symbolo condito tradidise, quam quod a temporibus Apostolorum, imo \& Prophetarum catholica, \& orthodoxa retinuerat Ecclesia."

8 Calvin, "Gratulatio," in Tractatus (see above, n. 5), 328: "non minus ex sanctis Patribus quam ex Scriptura fidem orthodoxam."

9 Calvin, Defensio sanae et orthodoxae doctrinae (see above, n. 6), 132.

10 Ibid., 149.

11 Calvin, "Responsio ad Versipellem," in Tractatus (see above, n. 5), 305, 313.

12 Jean Calvin, Institutionum christianae religionis IV, (Amsterdam: Johannes Jacob Schipper, 1667), III, c. 16, sect. 1 is called "Propositis Papistarum adversus orthodoxam de justificatione doctrinam calumniis."

13 Johann Micraelius, Lexicon philosophicum terminorum philosophis usitatorum, and ed. (Stettin: Jeremias Mamphrasius 1662): s.v. The digital archive "Lessici filosofici" consists of 21 dictionaries. 
uncontroversial and true in the sense that they are based upon Scripture and defined by ecumenical councils. ${ }^{14}$ What is new, however, is that Walaeus tends to identify the "orthodox church" with the Reformed Churches. He even once called the Synod of Dordt an orthodox council and thereby putting it on the same level as the ecumenical councils..$^{15}$ Moreover, Walaeus adds Libertinism, Socinianism, Anabaptism, and Arminianism to the ancient heresies. ${ }^{16}$ Finally, he seems to acknowledge that "orthodoxy" does not preclude all dissent in doctrinal matters, since he observes that the Synod of Dordt did not follow Gomarus in all of his teachings. ${ }^{17}$

The word "orthodoxy" does not appear in any of its forms either in the indices of the five volumes of Selected theological disputations held under the presidency of Gisbertus Voetius (1589-1676) or in the four volumes of his Church Politics. Voetius's starting point is the traditional framework. In his many works, the word "orthodox" primarily denotes an attribute of a doctrine, ${ }^{18}$ which is based upon Scripture and the old teachings of the church..$^{19}$ This doctrine, formulated by the Church Fathers and enacted by the ecumenical councils, will lead to communion and unanimity among Christians. ${ }^{20}$ Its truth is

14 Antonius Walaeus, Opera omnia, 2 vols. (Leiden: Adriaan Wyngaerden, 1647-1648), I, 37: "Vera ergo \& orthodoxa sententia est, quæ in concilio Ephesino \& Chalcedoniensi fuit definita"; I, 158: "Extra controversiam est inter Orthodoxos"; 275: "Consensus Orthodoxæ Ecclesiae and II, 145: "veritatem sententiæ orthodoxae ex Scripturis vindicemus" and 151: Augustini \& veteris Orthodoxæ Ecclesiae esse sententiam".

15 Ibid., I, 167: "contrarium tamen amplectuntur omnes Orthodoxi, etiam veteres Patres, \& omnes scholastici" (The "also" suggests a distinction between Reformed theologians on the one hand and the "Fathers" and the "Scholastics" on the other hand); Ibid., I, 175: "in veræ sententiæ \& Orthodoxae nostrarum Ecclesiarum demonstratione;" Ibid., II, 110: "ita quoque ut omnibus orthodoxa sententia Ecclesiae Reformatæ constaret, Synodus Dordracena eandem blasphemiam disertis verbis condemnavit".

16 Ibid., I, 9, "Libertines"; I, 37, 217, 298 "Anabaptists" and "Arminians": passim in Censura Corvini.

17 Ibid., I, 174: “Video inter Orthodoxos scriptores esse, qui eam non admittunt." Walaeus refers to God's scientia media, which is rejected by Gomarus, but received by other orthodox theologians.

18 Gisbertus Voetius, Politica ecclesiasticae partis primce libri duo posteriores, (Amsterdam: Johannes Janssonius van Waesberge, 1666), 165: "Fidem Christianam aut orthodoxiam" and "orthodoxæ religionis exercitium."

19 Voetius, Politicce ecclesiasticce partis primce libri duo priores (Amsterdam: Johannes Janssonius van Waesberge, 1663), 35. The orthodox church is also the public church (25).

20 Ibid., 98: "Implicitam omnium orthodoxarum ecclesiarum omniumque fidelium communionem, semper fuisse." Voetius, Politica ecclesiastica (see above, n. 18), 383: "veritate religionis \& unitate ecclesiae orthodoxæ." The primary task of synods is maintaining the unity of the orthodox. See Voetius, Politicce ecclesiasticce pars tertia (Amsterdam:Johannes 
established in an orthodox, methodical, and perspicuous way. ${ }^{21}$ If the church is divided into sects, it forfeits its orthodox nature. ${ }^{22}$ Vicious errors, schisms, and sects continuously endanger orthodoxy, ${ }^{23}$ but by resisting heresy, the church will remain one and universal. Therefore, within the Reformed tradition, words such as "orthodox" and "catholic" remained synonymous. ${ }^{24}$ In 168o, the Groningen theologian Johannes Braunius (1628-1708), for example, observed that the church of the New Testament is "catholic," unlike the church of the Old Testament, because it gathered its members from all peoples. This New Testament church may be called "orthodox," "as the Fathers assumed orthodox to be catholic."25

However, living during the apogee of the confessional age, Voetius makes confession the primary criterion of orthodoxy. The act of confession established the church, whilst its contradiction leads to heresy and blasphemy. ${ }^{26}$ A "confessio totalis" expresses all truths of faith that together lead to salvation. ${ }^{27}$ These truths are called the "fundamentals of faith." ${ }^{28}$ Voetius argues that heretics, such as the Arminians, at least partially, deny the need of a confession. ${ }^{29}$ A confession may be written by an individual, such as a prince or a bishop, or by an ecclesiastical body. An example of the first possibility is the confession of Cyril I, the patriarch of Constantinople, whom Voetius calls a true "orthodox" martyr. ${ }^{30}$ Confessions written by an ecclesiastical body are

Janssonius van Waesberge, 1676), 208; "cura religionis orthodoxae ... ad classes et synodos pertineat."

21 Gisbertus Voetius, "Praefatio ad lectorem," in Selectarum disputationum theologicarum pars I (Utrecht: Waesberge, 1668), ${ }^{* *} 3$ r.

22 Voetius, Politica ecclesiasticce pars secunda (Amsterdam: Johannes Janssonius van Waesberge, 1669), 431.

23 The primary cause of all error is the craving for novalty. See Voetius, Politicce ecclesiastica (see above, n. 22), 45 .

24 Voetius, Politicce ecclesiasticae (see above, n. 20), 502: "communionem, ... ecclesiae veræ, catholicae, orthodoxae, reformatæ." In 1630, the Leiden theologian André Rivet published the Latin version of a treatise, which was published earlier in French entitled Catholicus Orthodoxus, Oppositus Catholico Papistae, opposing the Reformed orthodox Christian to the Roman Catholic heretic.

25 Doctrina foederum, sive systema theologica didacticae et elencticae (Amsterdam: Abraham van Someren, 1691), 630: "vocatur Catholica 1. quia opponitur Ecclesiae Veteris Testamenti ... 2. quia est orthodoxa, prout apud Patres Catholicam sumitur pro Orthodoxo. Ridicule igitur Ecclesia Romana sibi soli arrogat titulum Catholica".

26 Voetius, Politica ecclesiasticae (see above, n. 22), 90.

27 Ibid., 91.

28 Voetius, Politica ecclesiastica (see above, n. 20), 19-21.

29 Ibid.

$30 \quad$ Ibid., 37 . 
called public confessions, symbols, or forms of consensus. Examples include the Nicene Creed or the Forms of Unity, which was enacted at the synod of Dordt. ${ }^{31}$ Their tenets are beyond dispute. ${ }^{32}$ An orthodox confession requires true knowledge, which in itself is sufficient in order to obtain salvation and to lead a Christian life.

The object of such genuine knowledge is God, who is known to all men. ${ }^{33}$ In the first sentence of his Institutes, Calvin had called the knowledge of God our highest wisdom. ${ }^{34}$ The Belgic Confession stated that we know God from nature as well. ${ }^{35}$ However, this knowledge of God by natural means is also part of philosophy, as is summarized in Cassiodorus's classic definition of philosophy as "the science of all things human and divine."36 It is on the basis of the fundamentally cognitive nature of a confession, that Reformed thought called for a continuous reflection on the link between philosophy and orthodoxy.

Only at the very end of the seventeenth century do we find a more historical conception of orthodoxy in Gottfried Arnold's Impartial History of the Church and of Heresy. ${ }^{37}$ Arnold argues that the so-called orthodox Fathers taught dangerous errors, were not pious at all, but acted out of greed, hypocrisy, intolerance, and tyranny. Since Constantine the Great, the doctrines of dominant parties in the Church, which were supported by secular authority, became orthodox, and divergent opinions were deemed heterodox. This focus on the relation between orthodoxy and power obviously lessened the truth claims of orthodoxy and diminished the potential conflict with philosophy.

31 Voetius, Politica ecclesiasticce (see above, n. 19), 286.

32 Ibid., 287: "Sed in formulis consensus confessionibus scil. \& catechesibus articuli proponantur tanquam verbo Dei definiti \& judicati, \& ab Ecclesia indicati."

33 Cf. H.A. Krop, "From Religion in the Singular to Religion in the Plural," in Enlightened Religion: From Confessional Churches to Polite Piety in the Dutch Republic, ed. J. Spaans and J. Touber [Brill's Studies in Intellectual History, 297] (Leiden, 2019), 30-31.

34 Calvin, Institutiones religionis Christianae (see above, n. 13), I, c. 1: "tota fere sapientiae nostrae summa, quae vera demum ac solida sapientia censeri debeat, duabus partibus constat, Dei cognitione \& nostri."

35 La confession de foy des eglises reformées des Pä̈-Bas (Amsterdam, 1687), 7.

36 Cassiodorus, De artibus ac disciplinis liberalium litterarum c.3, PL 70: 1167.

37 Th. Mahlmann, 'Orthodoxie' II, (see above, n. 2), 6: 1382. He here refers to Unpartheyische Kirchen- und Ketzer-Historie bis auf das Jahr Christi 1688 (Frankfurt, 1729). 
Voetius, even more than Waleaus, identified "orthodoxy" with his own confession. He often called the Reformed churches (and "our religion") "orthodox."38 Other churches and the Fathers ${ }^{39}$ are orthodox insofar as they are in agreement with the Reformed orthodoxy. ${ }^{40}$ Without hesitation, Voetius called the Synod of Dort "orthodox" and its rival confessions "heterodox."41

However, Voetius also acknowledges the obvious fact that a diversity of opinions and doctrine existed within the Reformed "orthodox" churches. His explanation for this is the distinction he made between the visible or external Church and the invisible or mystical Church. ${ }^{42}$ The visible Church and "orthodoxy" is of a basically human nature. The efficient causes of the Reformed church, Voetius observed, are "ministers," "consistories," and "the magistrate."43 In order to cope with the diversity of opinions within orthodoxy, Voetius underlined the need for moderation and tolerance. He called them the "positive means to preserve the regime of the church." 44 Their directing causes are prudence and fraternal love. Their goal is to maintain the peace and unity of the Church given the faulty human condition and erring conscience. ${ }^{45}$

Besides moderation and tolerance, Voetius introduces the concept of liberty. In the Reformed churches, there should be a liberty which is the golden mean between — on the one hand - Islamic servitude, which forbids all discussion about religion and Roman Catholic intolerance, which subjects all opinion

38 Voetius, Politicce ecclesiasticce (see above, n. 19), 128 (ministers), 148 (theologians), 208 (Reformed Church), 274 and 710 (religion), 290 (view), 368 (worship), 597 (the attitude of the orthodox towards organ music), 639, (our faith), 648 (the Reformed), 662 (parents); Voetius, Politica ecclesiasticae (see above, n. 18), 40. Voetius here dealt with interconfessional marriage of an orthodox person married to a non-Reformed.

Voetius, Selectarum disputationum theologicarum (see above n. 21), 78. In a proper sense, the word "Father" is used for "orthodox and confirmed authors till the death of Augustine." "Analogical" are writers from Augustine until Gregory the Great and "equivocally" medieval authors. All lack the authority to provide "a law, norm, or rule in reading Scripture or in issues of Faith" (82).

40 Voetius, Politica ecclesiasticae (see above, n. 18), 7. Voetius deals with the Waldensians and Bohemian Brethren.

41 In the letter to the reader in the Selected Theological Disputations Voetius argued that an orthodox theologian should be prepared to engage in controversies with "Pontificiis, Socinianis, Remonstranticis, Anabaptisticis, etiam Iudaicis".

42 Voetius, Politicae ecclesiasticae (see above, n. 19), 2, 11.

43 Ibid., 15 .

44 The title of Politica ecclesiasticae (see above, n. 20), lib. 2, tract. 2.

45 Ibid., 365 . 
to the judgement of the Holy See, and-on the other hand - the immoderate licence of libertines, Arminians, and "unhappy pacifiers between Protes-

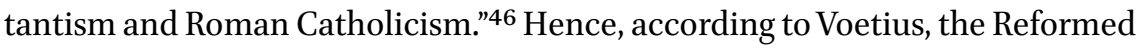
churches provided for a tempered freedom of opinion, speech, and teaching. ${ }^{47}$ There are four forms: 1 . liberty of conscience, which is absolute; ${ }^{48}$. liberty of speech giving no offence; 3 . academic or professional liberty; ${ }^{49}$ and 4 . theological freedom in the Church, limited by the fundamental tenets of the confession. ${ }^{50}$ The last two kinds Voetius calls the libertas prophetandi. ${ }^{51}$

Academic freedom, for example, is necessary in theology due to all kinds of chronological, geographical, and genealogical problems with respect to the text of the Bible. Voetius argued that theologians, although they are orthodox, will not solve these problems in the same manner, and therefore there should be some opportunity for criticism and correction in the church. ${ }^{52}$

With respect to philosophical matters, Voetius grants academic freedom to philosophers. It is, however, internally restricted by "the common principles of the natural light" and externally by other disciplines. Philosophy, therefore, should not intrude into the field of sacred philosophy, which rests upon biblical authority, by denying geocentricism and the sensitive soul in animals. ${ }^{53}$ More-

46 Ibid., 683-684: "Pugnant cum libertate prophetandi. 1. In defectu primo servitus \& tyrannis Muhammedica, perquam de religione non licet disquirere. [cf Spinoza's observations on "Turkish" religion in the preface of the TTP] Deinde servitus inquisitionis Papalis ... II. In excessu, Socinianorum, Remonstrantium, Vorstii, Acontii postulata libertas prophetandi, revera intolerabilis licentia: quippe qui eam ad fundamentalia, dogmata de Dei attributis, trinitate, persona \& officiis Christi \&c. extendunt."

47 Ibid., 679 .

48 Voetius, Politica ecclesiasticce (see above, n. 18), 401; H.A. Krop, "'The General Freedom, which all men enjoy' in a Confessional State: The Paradoxical Language of Politics in the Dutch Republic (1700-1750)," in Paradoxes of Religious Toleration in Early Modern Political Thought, ed. J.C. Laursen and M.J. Villaverde (Plymouth, 2013), 67-9o, there 22.

49 Voetius uses the phrases libertas scholastica or libertas in philosophicis. See Voetius, Politica ecclesiasticce (see above, n. 20), 686. Verbeek underlines that it meant the professional freedom. See Theo Verbeek, "Libertas philosophandi," in The Continuum Compenion to Spinoza, ed. Wiep van Bunge et al. (London, 2011), 252-253. According to Zenker, the actual Sitz im Leben of the notion is the confrontation between Aristotelianism and the New Philosophy from Ramism onwards. See Kay Zenker, Denkfreiheit: Libertas philosophandi in der deutschen Aufklärung (Hamburg, 2012), 38-90.

$50 \quad$ Voetius, Politica ecclesiasticce (see above, n. 20), 698.

51 Ibid., 679: “Ex his quatuor gradibus, duo posteriores proprie dicuntur libertas prophetandi; voce prophetandi acceptâ illa notione, quam Theologi ex 1 Corint. 14. accersunt. Duo priores gradus libertatis pertinent ad moderationem \& tolerantiam."

52 Ibid., 68o.

53 Ibid., 687 . 
over, philosophy should not undermine orthodox religion by arguing that the rational soul is a mode of the body, or that only thinking is the essence of man and not the body. All kinds of heretics use such forms of pseudo-philosophy to substantiate their errors. ${ }^{54}$ The liberty of philosophy turns into licence when philosophers transgress the limits of their discipline. Voetius gives two examples. The first is Hobbes who "in De cive dared to discuss justification, free will, and the reception of Christ in the Lord's Supper, as a philosopher."55 The second is Spinoza who "as philosopher took the licence to theologise and dealt with scriptural theology according to Cartesian method only."56 Although in the 1670 os Voetius rejected Cartesianism as passionately as he did in the 1640s, the orthodoxy he developed in his Church Politics (or Politica ecclessiastica) acknowledged the professional liberty of philosophers, which in principle did not exclude deviation from tradition.

\section{4}

\section{Reformed Orthodoxy in Practice}

The second part of this paper will outline two examples of philosophers who during the age of confessionalism actually made philosophy consistent with Reformed orthodoxy. Although professors at Leiden University were not obliged formally to subscribe to the decrees of Dordt, the confession was at the basis of all teaching at Reformed universities. ${ }^{57}$ This implied that Reformed philosophers, whatever their leanings, had to be prepared to argue that their views were in accordance with orthodoxy.

If we take a look at the establishment of Reformed orthodoxy at the Synod of Dordt, we will note that a substantial number of the delegates were professional philosophers. Their philosophical outlook was extremely diverse. Walaeus, for example, is a representative of humanist Aristotelianism, whereas William Ames championed Ramist anti-Aristotelianism. Among the German delegates, we encounter eclectic philosophers such as Matthias Martinius and

54 Ibid.: "plura istiusmodi pseudo-philosophemata, quae tanquam physica, aut Metaphysica, ab Epicureis, Socinianis aliisque ad haeresiarum suarum stabilimentem facile assumi possent."

55 Ibid., 687.

56 Ibid., 382: "Huc referri debet tract. Theologico-politicus, de libertate philosophandi nuper ab ex-Judeo quo, sed naturali $\psi v \chi \ltimes x \omega \hat{\omega}$ theologo ac philosopho, ubi prætextu libertatis philosophandi secundum methodum Cartesii licentiam quærit \& sumit contra veritatem Christianæ religionis, \& theologiam scripturariam theologizandi".

57 Dirk van Miert, Humanism in an Age of Science: The Amsterdam Athenaeum in the Golden Age, 1632-1704 [Brill's Studies in Intellectual History, 179] (Leiden, 2009), 24. 
Johan Heinrich Alsted. Notwithstanding these opposing philosophical views, all delegates signed the Canons of Dordt and accepted their philosophical core. ${ }^{58}$

I will outline how Aristotelianism was made consistent with the new Canons through the example of Walaeus. His main philosophical work is a manual on Aristotelian ethics, called Compendium ethicae Aristotelicae ad normam veritatis christianae revocatum, published in 1620 , immediately after Leiden University was purged of its Arminian teachers. The book was reprinted several times during the first half of the seventeenth century and was finally included in Walaeus's Opera omnia. Although the title promises that Aristotelian ethics will be judged according to the norm of Christian truth, Walaeus respects the Aristotelian tradition. In the preface, he defended the study of Plato and Aristotle at the University. These ancient authors have been of use even in the Reformed schools and churches. We should read and correct them with Christian liberty, Waleaus argues. ${ }^{59}$

Unlike his Leiden colleague Franco Burgersdijk who in his manual of moral philosophy disposed of the apparent conflict between Aristotelian moral philosophy and the Canons of Dordt in a short note, ${ }^{60}$ Walaeus dared to digress on predestination. He tackled the problem by starting with the Aristotelian list of the causes of action: intellect, will, deliberation, and choice. ${ }^{61}$ Human choice is possible with respect to the means, which are dependent on us, that is to say, which are within the limits of our powers. This, according to Walaeus, requires that our soul is free in its determinations from the causal links between physical causes and effects. Yet divine providence is not restricted to foreknowledge; it also includes God's determinations of all things, including our volitions. For God makes and produces all things that He wills. ${ }^{62}$ Walaeus continues his analysis with a discussion of the concept of liberty. Of the four kinds of "liberty" only the freedom to opt for a certain thing and at the same time to dismiss it, the so-called libertas contradictionis, is difficult to reconcile with the divine providence. ${ }^{63}$ However, Walaeus observes that divine providence is in fact acknowledged by nearly all philosophers. Only Epicurus denied such

58 H.A. Krop, "Philosophy and the Synod of Dordt: Aristotelianism, Humanism, and the Case against Arminianism," in Revisiting the Synod of Dordt (1618-1619), ed. Aza Goudriaan and Fred van Lieburg (Leiden, 2011), 49-80, there 50-51.

Antonius Walaeus, “Compendium ethicae Aristotelicae," in Opera omnia (see above, n. 14), 2, 259 .

6o Franco Burgersdijk, Idea philosophiae moralis (Leiden: Elzevir 1624), 6.24, 71.

61 Walaeus, "Compendium ethicae Aristotelicae," (see above, n. 59), 275.

62 Ibid., 277.

63 Ibid., 276. 
a faculty to the gods. Philosophers only argued about its mode of operation. On the one hand, there is Aristotle, who acknowledged a causal determination of all things but made an exception for human activities, because these are in our power. On the other hand, there are Stoic philosophers alleging a divine providence, which makes all things directly and immediately dependent on the first cause. This view annuls human freedom and subjects human will to fate. According to Walaeus, when placed in this dilemma, human reason should steer a middle course. ${ }^{64} \mathrm{~A}$ way out that is acceptable to moderate minds is to attribute to God such a power and wisdom that He created and determined human nature as a free nature leaving the will to its proper "motions." 65 Walaeus underpins his answer with the authority of Augustine but concedes that "these things are not very intelligible." ${ }^{\prime 6} \mathrm{He}$ takes the continuing controversy among philosophers as a proof of this fact. It is therefore by adopting an attitude of "learned ignorance" that Walaeus makes Aristotelianism to be in agreement with the new Reformed orthodoxy. The same applies for the New Philosophy.

\section{Cartesianism}

As Han van Ruler has argued, one of the main reasons why the Leiden theologian Abraham Heidanus (1597-1678) endorsed Cartesianism is that it offered a more intelligible solution than scholasticism to the conflict between divine providence and free will. ${ }^{67}$ Therefore, the new philosophy seemed more apt to underpin the confession.

Already during the 1640s, Heidanus engaged in confessional polemics with Remonstrantism. According to him, Arminianism was a revival of the ancient heresy of Pelagianism. Among the Roman Catholics, it was the Jesuits who endorsed it. This heresy assumes that a human being without sin is conceivable and that he or she would be able to save his or her soul without being justified by divine grace. Insofar as he was human, only Jesus Christ would not be stained with sin, Heidanus wrote. The argument shows a basic misconception of human moral powers by the Pelagians, and they are to be compared

\footnotetext{
64 Ibid., 277 .

65 Ibid.

66 Ibid.

67 J.A. van Ruler, "Reason Spurred by Faith: Abraham Heidanus and Dutch Philosophy," Geschiedenis van de Wijsbegeerte in Nederland 12 (2001), 21-28, there 23-25.
} 
with the builders of the Tower of Babel. ${ }^{68}$ The tradition of this basic heresy runs parallel to the tradition of orthodoxy, which starts with Augustine and ends, for Heidanus, with the Counter-Remonstrants. In calling upon his book Causa dei (God's case), Heidanus consciously imitated the example of Thomas Bradwardine, the first archbishop of Canterbury, who in the "Dark Ages" of Christianity defended orthodoxy. ${ }^{69}$ Like him, Heidanus opposes the anthropocentrism of the Pelagian heresy and pleads for God's case by stating, with the apostle Paul, that "all things are from God, through Him, and to Him."70

However, if all things depend upon God's will, Heidanus continued in a more philosophical vein, God provides for them and knows them eternally from Creation onwards. This is possible due to His necessary decree. The scholastic definition of free will, namely freedom of indifference, which is inspired by Plato and Aristotle, cannot be a correct definition of human freedom, since it denotes an imperfection and hence is not to be attributed to the will (which is a part of our mind), but only to the natural (i.e., bodily) inclinations of man. Augustine and "all those who philosophise reasonably and in proper order, provide for a better definition," that is to say "we are free if we act, as we want without being forced by an external power."71 The consequence of this definition, however, is that in the state of sin we cannot will freely. Forced by our natural inclinations, we are unable to will the good, but we will only sin. ${ }^{72}$ According to Heidanus, the impotence of natural man to act in a proper way does not make God the cause of sin, as the Arminians argue, because God is only permitting sin in a physical sense. The working of the first cause does not preclude that humans obey their inclinations. This definition of liberty also implies that we can only freely will the good and that we do so due to God's grace. In other words, according to the Causa dei, we are not free if our will is in balance between two alternatives. On the contrary:

68 Abraham Heidanus, “Toe-eygeninge aen de gemeente Leyden," in De causa Dei, dat is, de sake Godts, verdedight tegen den mensche (Leiden: Paulus Aertsz van Ravesteyn, 1645), ${ }^{3} 3 \mathrm{v}-$ $4 \mathrm{r}$.

69 Ibid., *** "That is why we gave our book the name De causa dei after the example of Thomas Bradwardine, Archbishop of Canterbury, who about 1325 gave his book against contemporary Pelagians the title De causa dei contra Pelagium."

$70 \quad$ Rom. 11,35. Therefore, Heidanus observed "all what man is, has and may do is of God." See Heidanus, De causa Dei (see above, n. 68), 665 .

71 Ibid., 131: "Augustine and all those who properly philosophize provide the following explanation: they call an action free if it is in our power, that is to say we perform it because we want it without being forced by an external power."

72 Ibid., 133: "we are free if our volitions are in our power and we find the good, that is we want to do the good and the good by enlightening us, empowers us to do the willed actions." 
the more we are inclined to something by clearly perceiving goodness and God ruling over our mind by His incomprehensible providence, the more we are free. Indeed, God's grace determining our will does not diminish our liberty but enhances it. ${ }^{73}$

Van Ruler observed that in the Causa dei, Heidanus simply translated the text of Meditation 4 into Dutch without ever mentioning Descartes's name. It is only during the controversies of the 165 os that Heidanus, in public, stated that predestination is reconcilable with Cartesian philosophy and that this philosophy is more useful to orthodoxy than other philosophies in reconciling free will with divine providence. ${ }^{74}$

Moreover, Heidanus not only attempted to prove that Cartesianism was more consistent with orthodoxy than Aristotelianism. The new philosophy also influenced his theology. In his theological course, he adopted Cartesian dualism by distinguishing between a corporeal and a spiritual substance, which are wholly independent of each other. Aristotle errs in suggesting that experience is the cause of the mind forming ideas. So, there are two substances. This Cartesian dualism implies that man is an intelligent substance united with a body, which is why Heidanus denounces the Aristotelian definition of man as a rational animal. Man is a composite entity, since his bodily motions are sharply distinct from his spiritual activities. His knowledge is more similar to the cognition of angels and God than to the perception of animals, if the intellect takes ideas as its object and not objects in the outside world. However, as a rule, our will drives the intellect beyond the boundaries of what is distinctly known. ${ }^{75}$

In the "locus on sin," Heidanus deals with the causes of sin. He starts by observing that the natural inclinations of our body produce our passions, which, as established by God, serve to stimulate our mind and to preserve our body. However, after the Fall, our judgement is blinded and unruly passions cause sinful actions. We become subjected to what St. Paul called "the law of

73 Ibid., 131; Van Ruler, "Reason Spurred by Faith" (see above, n. 67), 24.

74 Ibid., 24.

75 Abraham Heidanus, Corpus theologiae Christianae in quindecim locos digestum (Leiden: Jordanum Luchtmans et Johannem de Vivié, 1686), 314: "enim Homo sit compositus ex Mente \& Corpore, quorum utrumque sine alio potest distincte intelligi." See also 330 and 334 . 
sin.,76 According to Heidanus, only divine grace can emancipate us from this law. In this manner, the Leiden theologian adopted the Augustinian contrast between the life of the spirit and the life of the flesh, but he uses Cartesianism to clarify this orthodox theology. ${ }^{77}$

In 1676 , the governors of Leiden University forbade the teaching as well as the public and private discussion of some twenty theological and philosophical propositions, all of which were of a Cartesian origin. ${ }^{79}$ Heidanus compared this exceptional measure with the famous condemnation of Aristotle in thirteenthcentury Paris, because in the previous years the governing body stuck to the policy formulated by the States of Holland and treated old and new philosophy even-handedly. ${ }^{80}$ In 1656 , they passed their resolution ordering theologians and philosophers to stick to their own domain, which, as Grand Pensionary Johan de Witt wrote to his relative Heidanus, would preserve the "liberteyt van Philosopheeren" as far as possible. ${ }^{81}$

In Considerations regarding certain events, the last of his publications, Heidanus called the govenors' decree an infringement of ecclesiastical liberty, because in matters of theology and doctrine the church should decide in freedom, and not the magistrate who is without authority in these matters. Using the Reformed doctrine of the ius circa sacra, Heidanus observed that it is the competence of the prince to establish a public religion, but he should refrain from establishing its doctrine and confession..$^{82}$ Caustically, Heidanus

\section{$76 \quad$ Ibid., 499.}

77 Van Ruler, "Reason Spurred by Faith" (see above, n. 67), 25.

78 Abraham Heidanus, Consideratien over Eenige saecken onlanghs voorgevallen in de universiteit binnen Leyden (Leiden: Arnout Doude, 1676), 87. If there were no freedom to deal with subtile questions, one should have to prohibit Voetius's Disputationes selectae as well. Heidanus observed that all good wits would be quenched. This freedom, he adds unsurprisingly, should be used with "moderation" - sedicheyt — and should not undermine "de fundamenten van de Gereformeerde religie."

79 Printed in J.A. Cramer, Abraham Heidanus en zijn cartesianisme (Utrecht: Van Druten, 1889), 102-103.

8o Heidanus, Consideratien (see above, n. 78), 26.

81 Cramer, Abraham Heidanus (see above, n. 79), 73-74.

82 Heidanus, Consideratien (see above, n. 78), 12: "As the Sovereign Powers decide what will be the religion of the state ... and attempt to maintain its purity." On page 6, Heidanus refers to the freedom of conscience: "The forms of the Reformed Churches in the United 
compares the Govenors' resolution with the 1614 decree of States of Holland that prescribed certain opinions. It is well known, Heidanus observes, that the orthodox have denounced this presumption of secular authorities to be able to prescribe the correct interpretation of the Bible to theologians and ministers. ${ }^{83}$ Moreover, a simple banning of opinions, as the Governors had in mind, is pointless as history profusely has made obvious. In the Middle Ages, Aristotle was condemned several times, and in the sixteenth century, the same fate befell Petrus Ramus, but their opinions continued to be debated. ${ }^{84}$ The Governors' action may be explained by the need to maintain order, Heidanus continues, but unity and unanimity may not preclude our attempts to find truth.

In the second place, Heidanus argues that we should respect the distinction between the tenets of faith on the one hand and theological conclusions on the other. Controversy about theology has always been allowed by the orthodox in order to make progress in understanding divine truth. Accordingly, the church has always allowed for the liberty of dissent: in the controversy between Augustine and Jerome, Luther and Zwingli on the Last Supper, and Gomarus, whose supralapsarianism deviated from the decrees of the synod of Dordt, which enacted infralapsarianism. However, controversy on theological matters has to be argued with moderation and tolerance, Heidanus observes, since it is indispensable to find truth. ${ }^{85}$ Without the liberty "to explain and embellish the foundation once laid," we cannot "prove all things and hold fast to what is good." 86

In the third place, theology and philosophy should be distinguished in order to be free. Coccejus and Descartes asked for a clear separation, and Heidanus denounces the idea that philosophy should be the handmaiden of theology. We become aware of the disastrous consequence of this idea in the Roman Catholic Church, where the slave became the master and Aristotelianism ruled instead of theology. This is an old Reformed topos, but Heidanus uses it to sub-

Netherlands are to be signed, if they are considered to be in accordance with Holy Word of God."

83 Ibid., 10-11: "How all orthodox rejected this resolution with all force and the authority arrogated by the magistrate the judge about the explanation of Scripture and enforce its views upon the ministers of the Church is widely known."

84 Ibid., $26-27$.

85 Ibid., 17-19 and 22-23: "Since it is known that at the Synod of Dordt even D. Gomarus, an excellent member, although he was an adherent of supralapsarianism, was acknowledged as orthodox."

86 Ibid., 43: "I do not give way to the sowing of new doctrines, but I plead for the liberty to embellish and explain the foundations once laid." 
stantiate his claim that a theologian should be free to use the philosophy he considers to be the most useful. ${ }^{87}$

In a previous treatise, Heidanus had argued for the liberty to philosophise. There, he considers this freedom to follow directly from its nature. Since philosophising is nothing else but examining and finding the true causes of things by means of the natural light, a philosopher is unable to acknowledge the authority of another philosopher. ${ }^{88}$ In order to avoid prejudices and biases, he should only accept conclusions that he himself clearly and distinctly conceives to be true. This makes the philosopher a free and unbounded person who is his own master. ${ }^{89}$ Only such a free attitude makes progress in philosophy possible. By means of philosophising, Heidanus observed, Descartes discovered many truths, which otherwise would remain in the legendary pit of Democritus. ${ }^{90}$ It is impossible to take away this liberty by prescribing a specific philosophy, for example Aristotelianism, because it raises the question of which Aristotelianism is to be prescribed. There are so many differences between what Aristotle himself said and what contemporary Aristotelians teach. Actual Aristotelianism, according to Heidanus, is the result of a complex historical tradition and as such a mixed bag of opinions. ${ }^{91}$ Hence, it is inevitable that every philosopher judge for himself what is true, false, useful, or meaningless. ${ }^{92}$

Although Heidanus's orthodoxy was beyond dispute, the grey-haired theologian was fired. ${ }^{93}$ This dismissal caused so much public outrage that the other Cartesian professors at Leiden, the theologian Wittich and the philosopher De Volder, were left alone. Ever since, the liberty of philosophy was taken for granted and at the first centennial of the Synod of Dordt in 1719, Coccejus and Heidanus were honoured together with their Aristotelian adversaries. ${ }^{94}$ These examples show that in theory and practice the-limited-freedom to philosophise coexisted with orthodoxy as a "contested unity."

\footnotetext{
$87 \quad$ Ibid., 10-11.

88 Irenaeus Philalethius, Bedenkingen, op den staat des geschils, over de Cartesiaensche philosophie (Rotterdam: Johannes Benting, 1656), 3.

89 Ibid., 4.

90 Ibid., 5 .

91 Ibid., 8.

92 Ibid., 12: "If one takes way this liberty, one deprives a man of a basic quality needed to call him a philosopher ... It is possible to ask for a professor teaching a doctrine which runs against his conscience?"

93 Cramer, Abraham Heidanus (see above, n. 79), 153.

94 Wiep van Bunge, From Bayle to the Batavian Revolution [Brill's Studies in Intellectual History, 291] (Leiden, 2019), 123.
} 